\title{
PERJANJIAN PERKAWINAN PASCA PUTUSAN MAHKAMAH KONSTITUSI NOMOR 69/PUU-XIII/2015
}

\author{
Oken Shahnaz Pramasantya \\ Program Magister Kenotariatan Fakultas Hukum Universitas Brawijaya \\ Jl. MT. Haryono No 169; Malang; 65145; Indonesia; (0341) 553898 \\ okendsha.pramasantya@yahoo.com
}

\begin{abstract}
The Constitutional Court issued Decision Number 69 / PUU-XIII / where the marriage agreement was held after the marriage took place. Why the Constitutional Court allows the making of marriage contracts after marriage takes place. This study analyzes the legal considerations of the Constitutional Court judges in allowing marriage agreements to take place after the marriage takes place in accordance with the values of justice, as well as analyzing the legal implications of property of marriage agreements made after marriage in the event of any one of the injured parties. This research method is normative juridical. Based on the results of the study that the Marriage Agreement made after the marriage took place could potentially cause harm and injustice for third parties. Third-party interests also become unprotected. Regarding the time of entry into force of the Marriage Agreement made after the marriage takes place and in the Decision of the Constitutional Court Number 69/PUU-XIII/2015 in its verdict contained in point 1.5. and 1.6. raises a legal uncertainty. Third parties and husbands or wives who are harmed by the making of the Marriage Agreement after marriage take place may claim compensation and cancellation to the District Court.
\end{abstract}

Keywords: Legal Justice, Marriage Agreement, Third Party.

\begin{abstract}
Abstrak
Mahkamah Konstitusi mengeluarkan Putusan Nomor 69/PUU-XIII/ dimana perjanjian perkawinan dilaksanakan setelah perkawinan berlangsung. Mengapa Mahkamah Konstitusi mengijinkan pembuatan perjanjian perkawinan setelah perkawinan berlangsung. Penelitian ini, menganalisis pertimbangan hukum hakim Mahkamah Konstitusi dalam mengijinkan perjanjian perkawinan dilakukan setelah perkawinan berlangsung telah sesuai dengan nilai-nilai keadilan, serta menganalisis implikasi hukum terhadap harta benda dari perjanjian perkawinan yang dibuat setelah perkawinan apabila ada salah satu pihak yang dirugikan. Metode penelitian ini adalah yuridis normatif. Berdasarkan hasil penelitian bahwa perjanjian Perkawinan yang dibuat setelah perkawinan berlangsung dapat berpotensi menimbulkan kerugian dan ketidak adilan bagi pihak ketiga. Kepentingan pihak ketiga juga menjadi tidak terlindungi.Mengenai waktu berlakunya Perjanjian Perkawinan yang dibuat setelah perkawinan berlangsung serta dalam Putusan Mahkamah Konstitusi Nomor 69/PUU-XIII/2015 dalam amar putusannya yang terdapat dalam poin 1.5. dan 1.6. menimbulkan suatu ketidakpastian hukum. Pihak ketiga dan pihak suami atau istri yang dirugikan dengan pembuatan Perjanjian Perkawinan setelah perkawinan berlangsung dapat menuntut ganti rugi dan pembatalan ke Pengadilan Negeri.
\end{abstract}

Kata kunci: Keadilan Hukum, Perjanjian Perkawinan, Pihak Ketiga. 


\section{Pendahuluan}

Masalah hak dan kewajiban sebagai pasangan suami isteri dan masalah harta benda juga merupakan beberapa faktor pokok yang dapat menyebabkan timbulnya konflik di dalam perkawinan, bahkan dapat mengurangi kerukunan dalam rumah tangga. Dalam rangka mencegah konflik-konflik tersebut, maka dibutuhkan suatu perjanjian antara calon suami istri yang kemudian biasa kita sebut sebagai Perjanjian Perkawinan. Perjanjian dalam perkawinan merupakan perjanjian yang mengatur tentang akibat dari suatu perkawinan yang nantinya akan dilangsungkan. Perjanjian perkawinan ini isinya mengenai harta kekayaan walaupun tidak menutup kemungkinan isinya mengenai hal yang lain, seperti perjanjian tentang pengasuhan anak, dan lain sebagainya.

Perjanjian Perkawinan pada faktanya masih sangat jarang terjadi di Indonesia, hal tersebut mungkin dikarenakan masih kuatnya hubungan kekerabatan antara calon suami istri, dan juga pengaruh hukum adat yang masih sangat kuat. Perjanjian Perkawinan diatur dalam Bab VII Kitab Undang-Undang Hukum Perdata, mulai Pasal 139 sampai dengan Pasal 154. Khusus mengenai waktu pembuatan perjanjian perkawinan, diatur dalam Pasal 147 sampai dengan 149.

Perjanjian kawin menurut Kitab UndangUndang Hukum Perdata Pasal 139 adalah bentuk kesepakatan antara calon suami dan istri untuk mengatur atas harta kekayaan mereka dari perkawinan. Maka, perjanjian perkawinan akan mengatur pencampuran harta calon suami dan istri, atau mengatur adanya harta terpisah, yang berarti hartanya di luar persatuan.

Calon suami istri dapat membuat perjanjian perkawinan saat pelaksanaan atau bahkan sebelum perkawinan tersebut dilangsungkan, kedua belah pihak atas persetujuan bersama dapat menyusun perjanjian yang akan disahkan oleh Pegawai Pencatat Perkawinan. Namun pada tahun 2015, Mahkamah Konstitusi mengeluarkan Putusan Nomor
69/PUU-XIII/2015 yang mana dalam isinya, perjanjian perkawinan dapat dilaksanakan setelah perkawinan. Di sini terdapat perbedaan waktu pembuatan perjanjian perkawinan antara Kitab Undang-Undang Hukum Perdata, UU Perkawinan, Kompilasi Hukum Islam dengan Putusan Mahkamah Konstitusi.

Apabila perjanjian perkawinan tersebut dibuat setelah perkawinan dilangsungkan, maka dikhawatirkan adanya indikasi bahwa telah terjadi suatu masalah dalam perkawinan tersebut, padahal hakikat dibuatnya perjanjian perkawinan adalah untuk mencegah terjadinya suatu masalah tersebut sehingga dalam peraturan perundang-undangan dinyatakan waktu pembuatannya pada waktu sebelum perkawinan berlangsung atau pada saat perkawinan itu berlangsung. Karena pada waktu sebelum atau pada saat perkawinan berlangsung, kedua calon suami istri masih sama-sama memiliki itikad baik dalam melaksanakan perkawinan. Apabila perjanjian perkawinan dibuat setelah perkawinan, dikhawatirkan ada niat yang kurang baik dari salah satu pihak yang memiliki kepentingan tertentu berkaitan dengan harta kekayaannya.

Selain itu, dalam Kitab Undang-Undang Hukum Perdata disebutkan bahwa setelah perkawinan berlangsung, perjanjian kawin tidak boleh diubah dengan cara apa pun, demikian pula dalam Undang-Undang Republik Indonesia Nomor 1 Tahun 1974 tentang Perkawinan (UU Perkawinan) disebutkan pula seperti itu. Oleh karena itu, patut dipertanyakan, mengapa Mahkamah Konstitusi mengijinkan pembuatan perjanjian perkawinan setelah perkawinan berlangsung.

Adapun tujuan dari penulisan ini antara lain, yaitu untuk menganalisispertimbangan hukum hakim Mahkamah Konstitusi dalam mengijinkan perjanjian perkawinan dilakukan setelah perkawinan berlangsung telah sesuai dengan nilai-nilai keadilan. Serta untuk menganalisis implikasi hukum terhadap harta benda dari perjanjian perkawinan yang dibuat setelah perkawinan apabila ada salah satu pihak yang dirugikan. 


\section{Perjanjian Perkawinan Pasca Putusan Mahkamah Konstitusi Nomor 69/PUU-XIII/2015}

Oken Shahnaz Pramasantya

\section{Metode Penelitian}

Berdasarkan rumusan masalah dan tujuan yang telah diuraikan di atas, penelitian ini akan menggunakan metode penelitian yuridis normatif, karena dalam penelitian ini dilaksanakan studi dan analisis pada peraturan-peraturan yang tertulis atau bahan-bahan hukum yang lain sebagai objeknya disebabkan penelitian ini banyak dilakukan terhadap data yang bersifat sekunder yang ada di perpustakaan (Waluyo, 1991). Pendekatan penelitian dalam penelitian ini adalah metode pendekatan perundang-undangan (statute approach). Bahan hukum yang digunakan ialah bahan hukum primer dan bahan hukum sekunder.

\section{A. Dasar Pertimbangan Hukum Hakim Mahkamah Konstitusi Mengijinkan Perjan- jian Perkawinan}

Pertimbangan Hakim Mahkamah Konstitusi dalam 2 (dua) aspek yaitu:

\section{Aspek Yuridis}

1.1. Berkaitan tentang kewenangan Mahkamah Konstitusi

a. Berdasarkan Pasal 24C ayat (1) UndangUndang Dasar Negara Republik Indonesia Tahun 1974, Mahkamah Konstitusi berwenang mengadili pada tingkat pertama dan terakhir yang putusannya bersifat final untuk menguji undang-undang terhadap Undang-Undang Dasar, memutus sengketa kewenangan lembaga negara yang kewenangannya diberikan oleh Undang-Undang Dasar, memutus pembubaran partai politik, dan memutus perselisihan tentang hasil pemilihan umum.

b. Berdasarkan Pasal 10 ayat (1) huruf a Undang-Undang Nomor 24 Tahun 2003 tentang Mahkamah Konstitusi sebagaimana telah diubah dengan UndangUndang Nomor 8 Tahun 2011 tentang Perubahan Atas Undang-Undang Nomor 24 Tahun 2003 tentang Mahkamah Konstitusi,
Putusan Mahkamah Konstitusi bersifat final, yakni putusan Mahkamah Konstitusi langsung memperoleh kekuatan hukum tetap sejak diucapkan dan tidak ada upaya hukum yang dapat ditempuh. Sifat final dalam putusan Mahkamah Konstitusi dalam Undang-Undang ini mencakup pula kekuatan hukum mengikat (final and binding).

c. Pasal 29 ayat (1) huruf a Undang-Undang Nomor 48 Tahun 2009 tentang Kekuasaan Kehakiman, Mahkamah Konstitusi berwenang mengadili pada tingkat pertama dan terakhir yang putusannya bersifat final untuk: menguji undang-undang terhadap Undang-Undang Dasar Negara Republik Indonesia Tahun 1945; memutus sengketa kewenangan lembaga negara yang kewenangannya diberikan oleh Undang-Undang Dasar Negara Republik Indonesia Tahun 1945; memutus pembubaran partai politik; memutus perselisihan tentang hasil pemilihan umum; dan kewenangan lain yang diberikan oleh undang-undang.

1.2 Berkaitan tentang pengujian konstitusionalitas Pasal 29 ayat (1) Undang-Undang Nomor 1 Tahun 1974 tentang Perkawinan.

Pasal 28E ayat (2) Undang-Undang Dasar Negara Republik Indonesia Tahun 1945, Setiap orang berhak atas kebebasan meyakini kepercayaan, menyatakan pikiran dan sikap, sesuai dengan hati nuraninya.

2. Aspek Sosial

a. Bahwa perkawinan merupakan salah satu bentuk dari Hak Asasi Manusia. Sebagaimana terdapat dalam Pasal 28B ayat (1) Undang-Undang Dasar Negara Republik Indonesia Tahun 1945, Setiap orang berhak membentuk keluarga dan melanjutkan keturunan melalui perkawinan yang sah.

b. Bahwa didalam kehidupan berkeluarga atau berumah tangga, selain masalah hak 
dan kewajiban sebagai suami istri, masalah harta benda juga merupakan salah satu faktor yang dapat menyebabkan timbulnya berbagai perselisihan dalam suatu perkawinan dan menghilangkan kerukunan antara suami dan istri dalam kehidupan suatu keluarga. Untuk menghindari hal tersebut, maka dibuatlah perjanjian perkawinan.

c. Bahwa perjanjian perkawinan biasanya berisi janji tentang harta benda yang diperoleh selama perkawinan berlangsung, lazimnya berupa perolehan harta kekayaan terpisah, masing-masing pihak memperoleh apa yang diperoleh selama perkawinan itu termasuk keuntungan dan kerugian. Perjanjian perkawinan ini berlaku sebagai Undang-Undang bagi mereka yang membuatnya, juga berlaku bagi pihak ketiga yang memiliki kepentingan terhadapnya.

d. Bahwa yang menjadi landasan dibuatnya perjanjian perkawinan setelah perkawinan berlangsung adalah adanya kealpaan dan ketidaktahuan bahwa dalam UndangUndang Nomor 1 Tahun 1974 tentang Perkawinan, ada ketentuan yang mengatur mengenai perjanjian perkawinan sebelum perkawinan dilangsungkan.

e. Bahwa adanya resiko yang mungkin timbul dari harta bersama dalam perkawinan karena pekerjaan suami atau istri memiliki konsekuensi dan tanggung jawab pada harta pribadi, sehingga masing-masing harta yang diperoleh dapat tetap menjadi milik pribadi.

f. Bahwa dalam kenyataannya, ada fenomena suami istri yang karena alasan tertentu baru merasakan adanya kebutuhan untuk membuat perjanjian perkawinan setelah perkawinan tersebut berjalan (selama dalam ikatan perkawinan).
Berdasarkan pertimbangan-pertimbangan tersebut diatas, maka Hakim Mahkamah Konstitusi menyatakan:

i. Pasal 29 ayat (1) Undang-Undang Nomor 1 Tahun 1974 tentang Perkawinan (Lembaran Negara Republik Indonesia Tahun 1974 Nomor 1, Tambahan Lembaran Negara Republik Indonesia Nomor 3019) bertentangan dengan Undang-Undang Dasar Negara Republik Indonesia Tahun 1945 sepanjang tidak dimaknai, "Pada waktu, sebelum dilangsungkan atau selama dalam ikatan perkawinan kedua belah pihak atas persetujuan bersama dapat mengajukan perjanjian tertulis yang disahkan oleh pegawai pencatat perkawinan atau notaris, setelah mana isinya berlaku juga terhadap pihak ketiga sepanjang pihak ketiga tersangkut."

ii. Pasal 29 ayat (1) Undang-Undang Nomor 1 Tahun 1974 tentang Perkawinan (Lembaran Negara Republik Indonesia Tahun 1974 Nomor 1, Tambahan Lembaran Negara Republik Indonesia Nomor 3019) tidak mempunyai kekuatan hukum mengikat, sepanjang tidak dimaknai, "Pada waktu, sebelum dilangsungkan atau selama dalam ikatan perkawinan kedua belah pihak atas persetujuan bersama dapat mengajukan perjanjian tertulis yang disahkan oleh pegawai pencatat perkawinan atau notaris, setelah mana isinya berlaku juga terhadap pihak ketiga sepanjang pihak ketiga tersangkut."

iii. Pasal 29 ayat (3) Undang-Undang Nomor 1 Tahun 1974 tentang Perkawinan (Lembaran Negara Republik Indonesia Tahun 1974 Nomor 1, Tambahan Lembaran Negara Republik Indonesia Nomor 3019) bertentangan dengan Undang-Undang Dasar Negara Republik Indonesia Tahun 1945 sepanjang tidak dimaknai, “Perjanjian 


\section{Perjanjian Perkawinan Pasca Putusan Mahkamah Konstitusi Nomor 69/PUU-XIII/2015}

Oken Shahnaz Pramasantya

tersebut mulai berlaku sejak perkawinan dilangsungkan, kecuali ditentukan lain dalam Perjanjian Perkawinan."

iv. Pasal 29 ayat (3) Undang-Undang Nomor 1 Tahun 1974 tentang Perkawinan (Lembaran Negara Republik Indonesia Tahun 1974 Nomor 1, Tambahan Lembaran Negara Republik Indonesia Nomor 3019) tidak mempunyai kekuatan hukum mengikat, sepanjang tidak dimaknai, "Perjanjian tersebut mulai berlaku sejak perkawinan dilangsungkan, kecuali ditentukan lain dalam Perjanjian Perkawinan."

v. Pasal 29 ayat (4) Undang-Undang Nomor 1 Tahun 1974 tentang Perkawinan (Lembaran Negara Republik Indonesia Tahun 1974 Nomor 1, Tambahan Lembaran Negara Republik Indonesia Nomor 3019) bertentangan dengan UndangUndang Dasar Negara Republik Indonesia Tahun 1945 sepanjang tidak dimaknai, "Selama perkawinan berlangsung, perjanjian perkawinan dapat mengenai harta perkawinan atau perjanjian lainnya, tidak dapat diubah atau dicabut, kecuali bila dari kedua belah pihak ada persetujuan untuk mengubah atau mencabut, dan perubahan atau pencabutan itu tidak merugikan pihak ketiga."

vi. Pasal 29 ayat (4) Undang-Undang Nomor 1 Tahun 1974 tentang Perkawinan (Lembaran Negara Republik Indonesia Tahun 1974 Nomor 1, Tambahan Lembaran Negara Republik Indonesia Nomor 3019) tidak mempunyai kekuatan hukum mengikat, sepanjang tidak dimaknai, "Selama perkawinan berlangsung, perjanjian perkawinan dapat mengenai harta perkawinan atau perjanjian lainnya, tidak dapat diubah atau dicabut, kecuali bila dari kedua belah pihak ada persetujuan untuk mengubah atau mencabut, dan perubahan atau pencabutan itu tidak merugikan pihak ketiga."

\section{B. Pertimbangan Hukum Hakim Mahkamah Konstitusi Apabila Ditinjau dari Nilai-Nilai Keadilan}

Dasar Perjanjian Perkawinan adalah sama seperti perjanjian pada umumnya, sesuai dengan asas kebebasan berkontrak, kedua belah pihak diberikan kebebasan selama tidak bertentangan dengan undang-undaang, kesusilaan, atau tidak melanggar ketertiban umum. Kebebasan berkontrak diatur dalam Pasal 1338 ayat (1) Kitab UndangUndang Hukum Perdata yang menyatakan bahwa "Semua perjanjian yang dibuat secara sah berlaku sebagai undang-undang bagi mereka yang membuatnya." Hal tersebut juga telah ditentukan oleh Undang-Undang Dasar Negara Republik Indonesia Tahun 1974, tertuang dalam Pasal 28E ayat (2) yang mengatur bahwa setiap orang berhak atas kebebasan meyakini kepercayaan, menyatakan pikiran dan sikap, sesuai dengan hati nuraninya, termasuk menuangkannya kedalam suatu pernyataan dan perjanjian yang isinya dituangkan sesuai dengan pikiran dan hati nuraninya.

Namun, Pasal 1338 ayat (3) Kitab UndangUndang Hukum Perdata telah mengantisipasi kebebasan tersebut dengan asas itikad baik (good faith). Dalam asas ini mengharuskan para pihak harus membuat perjanjian dan melaksanakan substansi kontrak berdasarkan kepercayaan atau keyakinan yang teguh maupun itikad yang baik dari para pihak.

Kitab Undang-Undang Hukum Perdata pasal 147 menyatakan bahwa Perjanjian Perkawinan haruslah dibuat sebelum perkawinan berlangsung. Kemudian UU perkawinan dan Kompilasi Hukum Islam memberikan dua pilihan waktu untuk membuat Perjanjian Perkawinan sebagaimana dinyatakan dalam Pasal 29 ayat (1) UU Perkawinan dan pasal 47 ayat (1) Kompilasi Hukum Islam yang menyatakan bahwa pembuatan Perjanjian Perka- 
winan dapat dibuat pada waktu atau sebelum perkawinan dilangsungkan.

Kata "pada waktu" tersebut sebenarnya sudah cukup membuat masyarakat kebingungan, dikarenakan tidak adanya penjelasan dalam UU Perkawinan dan Kompilasi Hukum Islam mengenai kapan yang disebut dengan "pada waktu" tersebut, apakah pada saat perkawinan dicatatkan kemudian pada saat itu juga mencatatkan Perjanjian Perkawinan, ataukah pada saat pelaksaan ijab qabul (bagi agama Islam) juga langsung mencatatkan Perjanjian Perkawinan. Kemudian pada tahun 2015, keluarlah putusan Mahkamah Konstitusi yang menyatakan bahwa Perjanjian Perkawinan boleh dibuat setelah perkawinan dilangsungkan. Hal ini justru menimbulkan suatu ketidakpastian hukum mengenai kapan waktu dibuatnya Perjanjian Perkawinan.

Persoalan lain adalah alasan waktu pembuatan perjanjian perkawinan yang dibuat setelah perkawinan berlangsung. Dibutuhkan kepastian hukum terkait pembuatan Perjanjan Perkawinan yang dibuat setelah perkawinan berlangsung tersebut agar tidak memberikan dampak kerugian salah satu pihak atau pihak ketiga. Karena hakikat dibuatnya Perjanjian Perkawinan adalah untuk mencegah terjadinya suatu masalah yang mungkin akan muncul setelah perkawinan dilangsungkan. Namun apabila perjanjian tersebut baru dibuat setelah perkawinan berlangsung, dikhawatirkan adanya indikasi bahwa ada salah satu pihak yang ingin melindungi kepentingannya setelah terjadi masalah dalam perkawinan tersebut. Apabila benar terjadi demikian, maka pembuatan Perjanjian Perkawinan setelah

Fokuskan analisis tentang pertimbangan hukum hakim Mahkamah Konstitusi dengan menggunakan pisau analisa yaitu teori keadilan yang dikemukakan oleh Aristoteles. Aristoteles juga membagi keadilan menjadi dua macam, yaitu:

1. Keadilan distributif.

Keadilan ini dijalankan dalam rangka pembagian kehormatan, kemakmuran, dan aset-aset lainnya yang dapat dibagi dari komunitas, dimana asset-aset tersebut dapat dialokasikan kepada para anggotanya secara merata atau tidak merata oleh legislator dalam komunitas tersebut. Prinsip yang diterapkan dalam keadilan distributif adalah kesetaraan yang proporsional atau seimbang.

2. Keadilan korektif.

Keadilan korektif adalah keadilan yang memiliki prinsip korektif dalam hubungan antar individu. Penerapan keadilan korektif ini dilaksanakan oleh hakim dalam rangka menangani sengketa dan menjatuhkan sanksi pada pelaku kejahatan.

Ketentuan Pasal 29 ayat (1) UU Perkawinan sebenarnya justru memberikan kepastian hukum bagi para pihak yang mengikatkan dirinya dalam sebuah perkawinan. Perjanjian Perkawinan yang dibuat setelah perkawinan berlangsung dapat menimbulkan kerugian dan ketidak adilan bagi pihak ketiga. Kepentingan pihak ketiga juga menjadi tidak terlindungi.

Berkaitan tentang kapan mulai berlakunya Perjanjian Perkawinan, didalam Kitab UndangUndang Hukum Perdata, Undang-UU Perkawinan dan Kompilasi Hukum Islam, ketiganya telah mengatur secara jelas bahwa Perjanjian Perkawinan mulai berlaku sejak perkawinan dilangsungkan. Hal ini menurut penulis adalah wajar, karena pembuatan Perjanjian Perkawinannya telah dibuat sebelum perkawinan berlangsung.

Putusan Mahkamah Konstitusi Nomor 69/ PUU-XIII/2015 dalam amar putusan menyatakan bahwa "Perjanjian Perkawinan yang dilakukan setelah perkawinan, mulai berlaku sejak perkawinan dilangsungkan, kecuali ditentukan lain dalam Perjanjian Perkawinan." Hal ini kurang tepat, karena akan menimbulkan suatu ketidakpastian hukum. Ini disebabkan karena pemberlakukan Perjanjian Perkawinan yang dibuat setelah perkawinan tersebut dapat menimbulkan suatu permasalahan baru, yaitu mengenai kepastian hukum atas harta 


\section{Perjanjian Perkawinan Pasca Putusan Mahkamah Konstitusi Nomor 69/PUU-XIII/2015}

Oken Shahnaz Pramasantya

bersama yang diperoleh suami ataupun isteri antara rentang waktu dari tanggal perkawinan sampai dengan tanggal Perjanjian Perkawinan tersebut dibuat.

Bagi pihak yang ingin membuat Perjanjian Perkawinan setelah perkawinan berlangsung, sebaiknya agar dibuat bahwa Perjanjian Perkawinan tersebut berlaku terhitung sejak tanggal dibuatnya Perjanjian Perkawinan, bukan sejak perkawinan berlangsung. Sehingga akan tercipta suatu kepastian hukum serta agar tidak mengubah status hukum harta yang telah ada sebelumnya.

Putusan Mahkamah Konstitusi Nomor 69/ PUU-XIII/2015 dalam amar putusannya menyatakan bahwa, "Selama perkawinan berlangsung, perjanjian perkawinan dapat mengenai harta perkawinan atau perjanjian lainnya, tidak dapat diubah atau dicabut, kecuali bila dari kedua belah pihak ada persetujuan untuk mengubah atau mencabut, dan perubahan atau pencabutan itu tidak merugikan pihak ketiga." Hal ini menimbulkan suatu ketidakpastian hukum. Sebagaimana dalam UU Perkawinan Pasal 29 ayat (4). Dalam hal ini, akan menimbulkan suatu kelonggaran bagi pihak yang membuat Perjanjian Perkawinan setelah perkawinan, yang mana mereka dapat membuat Perjanjian lalu merubahnya, mencabutnya, dan membuat Perjanjian lagi yang baru dan seterusnya.

Berdasarkan penjelasan di atas menunjukkan Putusan Mahkamah Konstitusi Nomor 69/PUUXIII/ 2015 tidak menciptakan suatu keadilan. Dikarenakan hakim hanya memutuskan berdasarkan permohonan dari Nyonya Ike Farida dan saksisaksi yang merasa dirugikan karena menikah dengan Warga Negara Asing saja. Tidak melihat dampak-dampak lainnya yang akan timbul apabila Perjanjian Perkawinan tersebut dibuat setelah perkawinan berlangsung seperti yang telah diuraikan oleh penulis sebelumnya. Putusan Mahkamah Konstitusi tersebut juga malah menimbulkan suatu ketidakpastian hukum.

\section{Implikasi Hukum Terhadap Harta Benda dari Perjanjian Perkawinan yang Dibuat Setelah Perkawinan Apabila Ada Salah Satu Pihak yang Dirugikan}

Apabila Perjanjian Perkawinan tersebut dibuat setelah perkawinan berlangsung dan suami isteri telah membuat suatu perjanjian dengan pihak ketiga sebelum Perjanjian Perkawinan dibuat, maka Perjanjian Perkawinan tersebut tidak dapat mengikat terhadap pihak ketiga karena tidak ada kekuatan hukum. Sesuai ketentuan pasal 152 Kitab Undang-Undang Hukum Perdata tersebut, Perjanjian Perkawinan tidak akan berlaku bagi pihak ketiga sebelum Perjanjian Perkawinan tersebut tidak didaftarkan atau tidak di sahkan oleh pegawai pencatat perkawinan.

Apabila suami isteri yang ingin berbuat kecurangan terhadap pihak ketiga dengan cara membuat Perjanjian Perkawinan setelah perkawinan berlangsung tentunya akan sia-sia, dikarenakan Perjanjian Perkawinan tersebut tidak memiliki kekuatan hukum sehingga pihak ketiga menganggap bahwa perkawinan suami istri tersebut berlangsung dengan percampuran harta bersama. Sehingga apabila terdapat persangkutan hutang, maka suami maupun istri sama-sama memiliki tanggung jawab dalam menyelesaikan hutang tersebut. Apabila tidak ada Perjanjian Perkawinan, maka dengan sendirinya akan terjadi persatuan harta bersama.

Putusan Mahkamah Konstitusi Konstitusi Nomor 69/PUU-XIII/ 2015 dalam amar putusannya yang terdapat dalam poin 1.5. dan 1.6. juga menyatakan bahwa:

"Selama perkawinan berlangsung, perjanjian perkawinan dapat mengenai harta perkawinan atau perjanjian lainnya, tidak dapat diubah atau dicabut, kecuali bila dari kedua belah pihak ada persetujuan untuk mengubah atau mencabut, dan perubahan atau pencabutan itu tidak merugikan pihak ketiga."

Amar putusan tersebut sudah pasti menimbulkan ketakutan tersendiri bagi pihak ketiga, 
karena apabila suami atau istri dalam perjalanan perkawinan tersebut mengubah atau mencabut Perjanjian Perkawinan secara sepihak tanpa sepengetahuan pihak ketiga, maka sudah tentu akan sangat merugikan pihak ketiga. Amar putusan tersebut memberikan ruang bagi suami isteri untuk menghindar dan menyalahgunakan tanggung jawab dalam memenuhi kewajiban hutang terhadap pihak ketiga. Apabila ada salah satu pihak yang melakukan wanprestasi, maka pihak ketiga tersebut dapat menuntut ganti rugi ke Pengadilan Negeri.

Hal di atas berlaku apabila pihak ketiga memang tidak mengetahui tentang Perjanjian Perkawinan yang dibuat setelah perkawinan berlangsung dan Perjanjian Perkawinan tersebut belum atau tidak didaftarkan. Sedangkan pihak ketiga yang telah mengetahui adanya Perjanjian Perkawinan setelah perkawinan berlangsung namun telah didaftarkan, maka pihak ketiga tidak boleh menganggap bahwa Perjanjian Perkawinan tersebut tidak ada. Sehingga yang dapat mengajukan tuntutan adalah pihak ketiga yang melakukan perjanjian sebelum dibuatnya Perjanjian Perkawinan, ataupun telah dibuat Perjanjian Perkawinan, namun Perjanjian Perkawinan tersebut belum didaftarkan atau belum disahkan. Karena Perjanjian Perkawinan tersebut tidak memiliki kekuatan hukum yang tetap.

\section{Implikasi Hukum Bagi Salah Satu Pihak Suami atau Istri}

Sesuai dengan ketentuan Pasal 1338 Kitab Undang-Undang Hukum Perdata yang menyatakan bahwa:

"Semua persetujuan yang dibuat sesuai dengan undang-undang berlaku sebagai undang-undang bagi mereka yang membuatnya. Persetujuan itu tidak dapat ditarik kembali selain dengan kesepakatan kedua belah pihak, atau karena alasan-alasan yang ditentukan oleh undang-undang. Persetujuan harus dilaksanakan dengan itikad baik."
Berdasarkan bunyi Pasal tersebut maka semua perjanjian yang dihasilkan dari proses pembuatan yang sah, harus berlaku sebagai undangundang bagi para pihak pembuatnya.

Sesuai dengan asas lahirnya suatu perjanjian, yang disebut dengan asas konsensualisme, menyatakan bahwa "perjanjian lahir sejak saat tercapainya kata sepakat antara para pihak." Maka dengan secara langsung Perjanjian Perkawinan yang dibuat pada saat, sebelum maupun setelah perkawinan dilangsungkan sama-sama mengikat pihak-pihak yang terlibat dalam pembuatan perjanjian pada saat keduanya sepakat tentang Perjanjian Perkawinan yang dibuat.

Apabila terdapat permasalahan hutang piutang dengan pihak ketiga sebelum dibuatnya Perjanjian Perkawinan, maka diselesaikan sesuai Undang-Undang Nomor 1 Tahun 1974 tentang perkawinan, yaitu dengan percampuran harta. Maka apabila terdapat suatu hutang pribadi, yang wajib melunasi adalah pihak suami ataupun istri yang membuat perjanjian hutang tersebut, dan apabila pihak suami ataupun istri tidak dapat melunasi hutang tersebut, maka yang pertama disita oleh pihak ketiga adalah benda pribadi. Sedangkan apabila tidak terdapat beda pribadi ataupun ada tetapi nilainya tidak mencukupi, maka yang disita adalah harta bersama.

Dalam hal hutang persatuan, maka yang pertama dapat disita sebagai pelunasan adalah harta bersama. Dan harta pribadi yang pelunasannya dapat diambil dari harta bersama adalah perjanjian utang piutang dengan persetujuan pasangan. Maka, hutang yang dibuat oleh suami maupun istri yang tanpa sepengetahuan pasangannya tidak dapat dipertanggungjawabkan kepada harta pasangannya, dan tidak dapat diambil dari harta bersama.

Sedangkan untuk permasalahan hutang piutang setelah dibuatnya Perjanjian Perkawinan, mengikuti isi dari yang di perjanjikan. Apakah terdapat pemisahan harta atau persatuan harta keka- 


\section{Perjanjian Perkawinan Pasca Putusan Mahkamah Konstitusi Nomor 69/PUU-XIII/2015}

Oken Shahnaz Pramasantya

yaan, hutang piutang maupun perjanjian untung rugi antara pihak suami maupun istri, sesuai dengan kesepakatan dan persetujuan kedua belah pihak.

Apabila ada pihak yang mengalami kerugian dengan adanya Perjanjian Perkawinan yang dibuat setelah berlangsungnya perkawinan, seharusnya Perjanjian Perkawinan tersebut tetap mengikat kepada kedua belah pihak sehingga tidak dapat dicabut ataupun dibatalkan secara sepihak karena dibuatnya berdasarkan kesepakatan kedua belah pihak. Namun pada kasus tertentu, apabila memang salah satu pihak ada yang membuat Perjanjian Perkawinan secara sepihak untuk melindungi harta pribadinya, maka pihak lain dapat mengajukan suatu upaya hukum.

Berdasarkan Pasal 1365 Kitab Undang-Undang Hukum Perdata yang menyatakan bahwa,

"Tiap perbuatan yang melanggar hukum dan membawa kerugian kepada orang lain, mewajibkan orang yang menimbulkan kerugian itu karena kesalahannya untuk menggantikan kerugian tersebut."

Maka apabila Perjanjian Perkawinan yang dibuat setelah perkawinan berlangsung dan isinya merugikan salah satu pihak serta memenuhi syaratsyarat tersebut diatas, pihak yang dirugikan tersebut dapat menuntut pembatalan dari Perjanjian Perkawinan tersebut, dengan cara mengajukan gugatan perbuatan melawan hukum atas perjanjian yang dibuat tersebut kepada Pengadilan Negeri yang berkedudukan ditempat kediamannya.

\section{Kesimpulan}

Putusan Mahkamah Konstitusi Nomor 69/ PUU-XIII/2015 dalam amar putusannya yang terdapat dalam poin 1.5. dan 1.6. menurut penulis juga menimbulkan suatu ketidakpastian hukum. Karena akan berpotensi menimbulkan suatu kelonggaran bagi pihak yang membuat Perjanjian Perkawinan setelah perkawinan, yang mana mereka dapat membuat Perjanjian lalu merubahnya, men- cabutnya, dan membuat Perjanjian lagi yang baru dan seterusnya. Maka kepastian hukum yang telah dijamin dalam Kitab Undang-Undang Hukum Perdata dan UU Perkawinan menjadi tidak tercapai. Bagi pihak ketiga, apabila ada salah satu pihak yang melakukan wanprestasi sebelum dibuat Perjanjian Perkawinan, maka yang berhak untuk disita adalah harta pribadi dari yang berhutang, jika harta pribadi tersebut tidak ada, atau ada tetapi tidak mencukupi, baru kemudian pihak ketiga dapat melakukan penyitaan terhadap harta bersama.

Namun apabila pihak suami atau istri berdalih dengan mengatakan mereka sudah membuat Perjanjian Perkawinan setelah perkawinan berlangsung sedangkan pembuatan perjanjian utang piutangnya sebelum dibuat Perjanjian Perkawinan, maka pihak ketiga tersebut dapat menuntut ganti rugi ke Pengadilan Negeri. Hal tersebut berlaku apabila pihak ketiga memang tidak mengetahui tentang Perjanjian Perkawinan yang dibuat setelah perkawinan berlangsung dan Perjanjian Perkawinan tersebut belum atau tidak didaftarkan. Sedangkan pihak ketiga yang telah mengetahui adanya Perjanjian Perkawinan setelah perkawinan berlangsung namun telah didaftarkan, maka pihak ketiga tidak boleh menganggap bahwa Perjanjian Perkawinan tersebut tidak ada.

\section{Saran}

Sebaiknya pembuat Undang-Undang melakukan revisi terhadap Undang-Undang Perkawinan khususnya mengenai Perjanjian Perkawinan agar sesuai dengan Putusan Mahkamah Konstitusi agar tidak ada lagi konflik norma yang bersifat horizontal ekstern, karena terjadi perbedaan aturan antara Kitab Undang-Undang Hukum Perdata, Undang-Undang Nomor 1 Tahun 1974 tentang perkawinan, Kompilasi Hukum Islam, dengan Putusan Mahkamah Konstitusi nomor 69/PUU-XIII/ 2015. Sehingga dapat mencapai kepastian hukum dan keadilan dikemudian hari. Karena pada kenyataannya masalah dalam masyarakat semakin berkem- 


\section{Jurnal Cakrawala Hukum \\ Vol.8, No.2 Desember 2017: 191-200}

bang, dalam hal ini tentang waktu pembuatan Perjanjian Perkawinan.

\section{DAFTAR PUSTAKA}

Waluyo, Bambang. 1991. Penelitian Hukum Dalam Praktek. Sinar Grafika. Jakarta.

Kitab Undang-Undang Hukum Perdata.

Kompilasi Hukum Islam.

Penetapan Nomor 207/Pdt/P/2005/ PN. Jkt. Tim. Penetapan Nomor 459/Pdt/P/2007/PN. Jkt. Tim.
Putusan Mahkamah Konstitusi Nomor 69/PUU-XIII/ 2015.

Putusan Nomor 526/Pdt/G/2012/PN. Jkt. Sel.

Undang-Undang Nomor 1 Tahun 1974.

\section{How to cite:}

Pramasantya, Oken Shahnaz. 2017. Perjanjian Perkawinan Pasca Putusan Mahkamah Konstitusi Nomor 69/Puu-Xiii/2015. Jurnal Cakrawalah Hukum, 8(2). 